Article Type: Research Paper

\title{
The Effect of External and Internal Factors on Financial Performance of Islamic Banking
}

\author{
Muhammad Istan $^{1}$ and Mochammad Fahlevi ${ }^{2 *}$
}

\section{OP opEN}

\section{AFFILIATION:}

${ }^{1}$ Institut Agama Islam Negeri Curup. Bengkulu, Indonesia

${ }^{2}$ Universitas Bina Nusantara. Jakarta, Indonesia

\section{*CORRESPONDENCE:}

mochammad.fahlevi@binus.ac.id

\section{THIS ARTICLE IS AVALILABLE IN:}

http://journal.umy.ac.id/index.php/esp

DOI: 10.18196/jesp.21.1.5036

\section{CITATION:}

Istan, M., \& Fahlevi, M. (2020). The Effect of External and Internal Factors on Financial Performance of Islamic Banking. Jurnal Ekonomi \& Studi Pembangunan, 21(1), 137145.

\section{ARTICLE HISTORY \\ Received:}

20 January 2020

Reviewed:

26 April 2020

Revised:

27 April 2020

Accepted:

28 April 2020

\begin{abstract}
Macroeconomic factors and internal factors are variables that affect sharia banking. These factors are GDP, inflation, and interest rates, FDR, OER, which can affect directly or indirectly, the financial performance of sharia banks in Indonesia. The result has shown GDP has a significant positive effect on ROA, it is matching with several previous research, Inflation has no significant and negative effect on ROA, because when inflation central bank will give policy to increase $\mathrm{BI}$ rate, and sharia bank doesn't affect with interest rate because interest is riba, interest rate has no significant effect on ROA because sharia bank doesn't effect with interest but use profit and loss sharing to financing, so in macroeconomic the result only GDP has significant and positive effect on ROA. The result has shown FDR has no significant effect on ROA but has positive effect and the result match with previous research in relationship FDR and ROA, OER has a significant negative effect on ROA.

Keywords: GDP; Inflation; Interest Rate; FDR; ROA.

JEL Classification: H3O; E22; O23; 011.
\end{abstract}

\section{Introduction}

The existence of sharia banking for the past 20 years has given its color to the financial industry in Indonesia, particularly the banking industry. However, until now the market share of sharia banking has only reached $4.23 \%$ of the total national banking. One issue that arises is about the determinants of the level of profit (financial performance) in sharia banking. Chapra (2008) stated that recent financial innovations are so complex that the gigantic conventional financial institutions and financial analysts had failed to assess the inherent financial risk accurately on their securitised loans. According to Muslim scholars, the recent financial crisis in the US and the rest of the world was caused to a significant extent by excessive and imprudent lending (market discipline), the structure of the system with inadequate regulations and the imprudent practices (greediness). The strategic steps of sharia banking development that have been attempted are the granting of licenses to conventional commercial banks to open sharia business units or to convert a conventional bank to sharia banks. With the issuance of Government Regulation No. 72 of 1992 concerning profit sharing banks that expressly provide a limitation that "profit-sharing banks may not conduct business activities that are not based on the principle of profit-sharing (interest), on the contrary the bank whose business activities are not based on profit sharing principles 
are not allowed to conduct business activities-based profit sharing "(article 6), the way for sharia banking operations is broader. At present the culmination point has been reached with the passage of Law No.21 of 2008 about sharia bank regulating the system of sharia banks.

To assess the development of sharia banks from year to year, several standards are usually used, including: [1] Amount of assets, [2] Third-party funds, and [3] Bank financing. At present, there are 11 sharia commercial banks in Indonesia. According to the Bank's Published Financial Report issued by Bank Indonesia, as of September 31, 2013, the assets of sharia commercial banks reached IDR 196.922 trillion. The funds raised by sharia banks will certainly increase, considering that the Ministry of Religion currently entrusts the management of the Hajj funds to the appointed sharia banks.

The limited involvement of government funds in the sharia banking industry has been proposed by Ariff and Ramadili Mohd (1998). Ismail (2011) tends to categorise sharia banking in Indonesia as informal arrangements. The intention is that sharia banking comes from the demand of the downstream. This situation is certainly related to the government's strong commitment to fight for sharia banking. Furthermore, because the last one, according to Ismail (2011) is the limited number of unattainable sharia banking networks and insufficient socialisation of the banks. One more reason for the few sharia banking markets share in Indonesia is the role of ulama and Islamic organisations in Indonesia.

According to Yunus (2008), in his empirical study in Pekanbaru found that the Indonesian Islamic Scholar Council (MUI) affected the development and dissemination of sharia banking. As also found in the quantitative study carried out by Kurniawan (2010), it shows that the ratio of sharia banking financial performance rate is improving with the existence of the MUI fatwa in 2004 concerning bank interest prohibition laws. The results of this study also indicate a different of the sharia banking financial performance before and after the MUI fatwa regarding bank interest. However, according to Abduh and Omar (2010) the impact is not so significant on the addition of consumers, namely those who move their money to sharia banks, the amount is not comparable to those who do not move their money. Wahyuni (2009) further stated that the MUl fatwa was "only" able to increase third-party funds by as much as $25 \%$ from the previous one and did not have significant implications for the total addition of total sharia banking assets. A part from the slight impact of the role of the ulama and religious unity he still gives effect.

Macroeconomic indicators play an important role in stabilising economy. A stable economy can be seen from the results of profits or profitability of banking financial institutions. One macroeconomic indicator which can be used to see the economic stability of a country is inflation because changes in this indicator will have a direct impact on the dynamics of economic growth. Inflation is one of the macroeconomic variables. The occurrence of inflation will affect the amount of money circulating and is also the monetary policy that the government does through central bank. The money circulating will be controlled by the government in a way that affects the process of making money. 
Liquidity ratio as the proxy for Financing to Deposit Ratio (FDR) is used as a variable that might affect ROA.

There is a conflict of interest between liquidity and profitability. If you want to maintain a liquidity position with enlarge cash reserves, the bank will not use all loanable funds that exist because in part returned in the form cash reserve; this means efforts to achieve profitability will reduce. Conversely if the bank wants to enhance profitability, then with cash reserve for used liquidity by the bank's business so that the position liquidity will go down (Muchdarsyah, 2000). If this ratio increases within the limit certain funds will increase, which is distributed in the form financing, so it will increase bank profits, assuming the bank distributes funds for effective financing. With increase in profits, then Return on Assets (ROA) will also increase, because profit is a component forming Return on Asset.

OER is a ratio that shows the ability of the bank to run its operations efficient. The theory explains that the relationship between EOR and ROA is inversely proportional. Number the standard for OER ratio is below $90 \%$ (PBI), if the OER ratio more than one bank produces $90 \%$, it can be concluded that the bank is not inefficient operate it. If ratio OER is in a condition of efficiency, profit the greater will be obtained because operating costs are borne by the bank getting smaller. With increasing profit, it can be ascertained that ROA can increase. The research done by Mawardi (2005), concluded that OER negative effect on performance bank that is proxied by ROA. In the last four decades, a lot of research has been conducted to test the determinants of the conventional bank's financial performance rate. The research was first done by Hester and Zoellner (1966) then further research was conducted by Bourke (1989); Molyneux and Thornton (1992); Short (1979); Steinherr and Huveneers (1994).

Even if viewed from the aspect of asset development, capital and Sharia banking institutions show positive developments. Even the average growth of Sharia banking so far $(47 \%)$, is higher than the average growth of conventional banking, which is only around $15-20 \%$ per year. However, when viewed from the overall market share, the overall Sharia banking is still too small compared to conventional banking. After two decades of Sharia banking operating in Indonesia, the market share is only 3.2\% of the total market share of the national banking industry. The reality, as above is termed by Adnan (2010) that the control of public funds by Sharia banking is still low. This situation, similarly, means that Sharia economics is still in the stage of opinion, where the evidence is only about $3 \%$ of Sharia banking takes an economic role in Indonesia. This number is very small, and it does not fit for Indonesia, which dominates its population to be Muslim (Amin, 2010).

This situation is, of course rather disappointing as Rais (2008) stated that the small market share is caused by limited funds both in terms of capital and the number of public funds collected. The small amount of public funds in Sharia banking has implications for the small share of the Sharia banking market. This situation finally embodies the issues related to consumer uncertainty and the issue of Muslim consumer compliance with Sharia banking. 
Research on the sharia bank financial performance level was first conducted by Haron (1996), then similar research was conducted by Ahmad and Safwan (2011); Akhtar, Ali, and Sadaqat (2011). Macroeconomic factors and internal factors are variables that affect sharia banking. These factors are GDP, inflation, and interest rates, FDR, OER, which can affect directly or indirectly, the financial performance of sharia banks in Indonesia. The novelty of this study is to combine the two factors, namely external and internal effects on the financial performance of Islamic banks in Indonesia.

This research has an important contribution to Islamic banks in Indonesia, that is, knowing the impact of macroeconomic changes as external factors and the impact of internal factors, specifically the influence of operational and FDR on the financial performance of Islamic banks in Indonesia. The results of this study can be used by management to develop strategies as a mitigation measure to reduce risk caused by the influence of external and internal factors in Islamic banks in Indonesia.

\section{Research Method}

This research uses quantitative descriptive research. Descriptive method is a method based on analysis by describing factors related to the problem that are intended as support for quantitative method analysis. While the quantitative method is research conducted to find various variables that are the object of research. While the estuary of this research is library research. The object of this research is the level of the financial performance of sharia banks, which are affected by macroeconomic factors and internal factors. To study and verify the impact of the macroeconomic factors and internal factors on Islamic commercial banks in Indonesia.

The sample in this study was chosen according to its characteristics using a purposive sampling method. The purposive sampling method is a method of determining the sample based on certain criteria. The criteria used in this study are: (1) Banks included in sharia commercial banks, (2) The bank operates and issues quarterly financial reports during the study period, first quarter 2013 to third quarter 2017. (3) Dual banking system or full pledge system.

Table 1 Research Variables

\begin{tabular}{ll}
\hline \multicolumn{1}{c}{ Variables } & RESEARCH VARIABLES \\
\hline $\begin{array}{l}\text { dependent variable } \\
\text { Return on investment (ROA) } \\
\text { Independent Variables }\end{array}$ & Quarterly Islamic Banking financial statements \\
$\begin{array}{l}\text { Gross Domestic Product (GDP) } \\
\text { Inflation }\end{array}$ & National Central Statistics Agency data report \\
Interest Rate & Indonesian Monetary Policy Report - Bank Indonesia \\
\hline Financial to Deposit Ratio & Indonesian Monetary Policy Report - Bank Indonesia \\
Operational Efficiency Ratio & Quarterly Islamic Banking financial statements \\
\hline
\end{tabular}

Source: Author, 2020 
Linear regression is a statistical tool used to determine the effect of one or several variables on one variable. Variables that effect are often called independent variables, independent variables or explanatory variables. The variable that is affected is often called the dependent variable or dependent variable.

\section{Result and Discussion}

In this section, the results of the analysis of multiple linear regression and the discussion and discussion will be discussed. The researcher has formulated the regression which is as follow.

$$
\text { ROAi,t= b0 + b1GDPi,t + b2INFi, t + b3 IRi,t+b4 FDRi, t+ b5 OERi,t+e }
$$

Table 2 Coefficients

\begin{tabular}{lccc}
\hline \multicolumn{1}{c}{ Model } & \multicolumn{2}{c}{ Unstandardized Coefficients } & Sig. \\
& $\mathrm{B}$ & Std. Error & \\
\hline (CONSTANT) & -6.774 & 6.236 & .280 \\
\hline INFLATION & -.011 & .016 & .479 \\
\hline INTEREST & .023 & .024 & .341 \\
FDR & .001 & .003 & .640 \\
OER & -.092 & .005 & .000 \\
LN_GDP & 1.082 & .430 & .014 \\
\hline
\end{tabular}

Source: Author, 2018

The coefficient table presents information consisting of the names of variables, the value of constant (Constant), the value of $t$ and the value of significance. Whereas the beta value on the standardised coefficient does not need to be discussed here because the value will be useful if you do path analysis now the researcher is not analysing the path.

In the table above we can observe that GDP has a sig value of 0.014 . This value is smaller than 0.05 , or value of $0.014<0.05$, then hypothesis 1 can be accepted, namely that GDP has a significant positive effect, as well as the OER variable has a sig value of 0,000 . So, it can be concluded that hypothesis 5 is accepted; from this information, it can be concluded that the OER variable has a negative and significant effect. From the data in the table above we can make the regression formula equation as follows:

$$
\text { ROAi,t=(6.774) + 1.082 GDP- 0,092 OER }
$$

Gross domestic product (GDP) are defined as one of the macroeconomic indicators the mostly used to computed total economic activity, which can influencing various factors both in the demand and supply of service banking. Ramadan, Kilani, and Kaddumi (2011) have concluded that there is a relationship positive between GDP and bank profitability. The impact of the socialisation of innovation will increase a country's income by suppressing funds abroad, in the sense of royalty payments on licensed technology. 
The Effect of External and Internal Factors on Financial Performance of Islamic Banking

Intellectual property assets such as patents for inventors, the right to duplicate for authors, composers, or mineral resources (oil, gas, metal materials and other mines). For this reason, efforts are needed to support the acceleration of development through the development of innovations in various fields.

OER, according to the financial dictionary is a ratio group that measures operational efficiency and effectiveness companies with comparing lines one against the other. Various numbers income and expenditure from the reported profit and loss to numbers on the balance sheet. Operational Efficiency Ratio (OER), provides a comparison between operating expense and operating income. With a bigger the OER, the bank's ROA gets smaller, because of the profit earned by the small bank. This finding has received considerable other support by Ma'isyah and Mawardi (2015).

Islamic banks as financial intermediary institutions are expected to show better performance compared to interest-based banks. One indicator to assess bank financial performance is to see the level of profitability and the level of efficiency. The profitability measure used is Return on Assets (ROA). ROA focuses the company's ability to obtain earnings in the company's operations. The greater ROA shows better financial performance, because the rate of return is greater (Sahara, 2013). GDP is a macroeconomic indicator that also affects bank profitability. If GDP rises, it will be followed by an increase in public income so that the ability to save also increases. This increase in saving will affect the profitability of Islamic banks (Sukirno, 2003). This result is reinforced by the results of research conducted by Ali et al. (2011) conducted at commercial banks and Islamic banks in Pakistan, where the results of his research concluded that the Gross Domestic Product (GDP) has a significant positive relationship with the amount of savings collected by banks in Pakistan.

Stable profitability is the goal of all companies, occurring in many cases of companies in Indonesia, especially conventional companies that have a high level of volatility, causing management to manipulate earnings which is contrary to Islamic principles (Fahlevi, Moeljadi, Aisjah, \& Djazuli 2020). Operations are one of the important things in determining the profitability of banks, especially Islamic banks that are still trying to expand into the market in Indonesia. The OER ratio shows the efficiency of banks in running their main business, especially loans, where credit interest is the biggest income of banks. Funding management is very much needed by banks, bearing in mind the function of financing as the biggest revenue contributor for Islamic banks. The smaller the OER shows the more efficient the bank is in carrying out its business activities. Banks with a healthy OER ratio are less than 1 , whereas banks that are less healthy have a OER ratio of more than 1 . The higher the cost of bank revenue means the operational activities are more inefficient so that their income is also smaller. In other words, OER is negatively related to bank profitability. This result is supported by Yuliani (2007), Mawardi (2005) and Azwir (2006) who state that OER has a significant negative effect on ROA. 


\section{Conclusion}

In service providing economies, the banks play very crucial role as a financial intermediary and also considered very important for economies functions. The economic growth can also affect financial intermediation efficiency. Moreover, insolvencies of bank can lead to crisis as a whole. The banking sector profitability contributes in economies and makes economies to endure negative and external financial shocks and contribute in financial system stability. For that reason, understanding of profitability determinants is crucial. This research is focusing on the relationship between external and internal factors to financial performance. GDP has a significant positive effect on ROA, it is matched with Haron (1996), because when inflation central bank will give policy to increase BI rate, and sharia bank is not affected by interest rate because interest is "riba" which means prohibited. Therefore, in terms of macroeconomic variable, result shows that, only GDP has significant and positive effect on ROA. FDR has insignificant effect on ROA and the result match with Muchdarsyah (2000) in relationship FDR and ROA, OER has negative significant effect on ROA, the result match with Mawardi (2005).

\section{References}

Abduh, M., \& Omar, M. A. (2010). Who Patronises Islamic Banks in Indonesia. Australian Journal of Islamic Law, Management and Finance, 1(1), 40-53.

Adnan, A. A. (2010). Penentu pemilihan institusi perbankan Islam dalam kalangan Muslim di Terengganu. Thesis. Universiti Sains Malaysia. Retrieved from http://eprints.usm.my/41881/1/Ahmad_Azrin_Adnan_HJ.pdf

Ahmad, A., \& Safwan, N. (2011). Testing A Model of Islamic Banking based on Service Quality, Customer Satisfaction and Bank Performance. African Journal of Business Management, 5(5), 1880-1885. https://doi.org/10.5897/AJBM10.982

Akhtar, M. F., Ali, K., \& Sadaqat, S. (2011). Factors Influencing the Profitability of Islamic Banks of Pakistan. International Research Journal of Finance and Economics, 66, 1-8.

Retrieved from http:/ / citeseerx.ist.psu.edu/viewdoc/download?doi=10.1.1.458.8877\&rep=rep1\&typ $\underline{e=p d f}$

Ali, K., Akhtar, M. F., \& Ahmed, H. Z. (2011). Bank-specific and macroeconomic indicators of profitability-empirical evidence from the commercial banks of Pakistan. International Journal of Business and Social Science, 2(6), 235-242. Retrieved from http://joc.hcc.edu.pk/faculty publications/bankspecific.pdf

Amin, A. R. (2010). Menggagas manajemen syariah (Teori dan praktik the celestial management). Jakarta: Salemba Empat.

Ariff, M., \& Ramadili Mohd, S. M. (1998). Stock pricing in Malaysia: corporate financial \& investment management. Malaysia: Universiti Putra Malaysia Press.

Azwir, Y. (2006). Analisis Pengaruh kecukupan modal, efisiensi, likuiditas, NPL, dan PPAP terhadap ROA bank. Thesis. Universitas Diponegoro. Retrieved from http://eprints.undip.ac.id/15950/

Bourke, P. (1989). Concentration and other Determinants of Bank Profitability in Europe, North America and Australia. Journal of Banking \& Finance, 13(1), 65-79. https://doi.org/10.1016/0378-4266(89)90020-4 
Chapra, M. (2008). The Islamic Vision of Development. Thoughts on Economics. The Quarterly Journal of Islamic Economics Research Bureau (Bangladesh), 18(3), 7-38.

Fahlevi, M., Moeljadi, Aisjah, S., \& Djazuli, A. (2020). The Impact of Board Independence and CEO Education on Earning Manipulation Beneish M-Score Models. Test Engineering \& Management, 83(MArch-April 2020), 18264-18276. Retrieved from https://www.researchgate.net/publication/341188545 The Impact of Board Indep endence and CEO Education on Earning Manipulation Beneish M$\underline{\text { Score Models }}$

Haron, S. (1996). Competition and Other External Determinants of the Profitability of Islamic Banks. Islamic Economic Studies, 4(1). Retrieved from https://ssm.com/abstract $=3165363$

Hester, D. D., \& Zoellner, J. F. (1966). The Relation between Bank Portfolios and Earnings: An Econometric Analysis. The Review of Economics and Statistics, 48(4), 372-386. https://doi.org/10.2307/1924615

Ismail, P. S. (2011). Perbankan syari'ah. Jakarta: Kencana Prenada Media Group.

Kurniawan, B. (2010). Perbedaan Profitabilitas Bank Syariah Sebelum dan Sesudah Adanya Fatwa MUI tentang Bunga Bank. Jurnal Iqtishoduna, 6(2). Retrieved from http://scholar.google.com/scholar?cluster=8748326927066094927\&hl=en\&oi=schol arr

Ma’isyah, R., \& Mawardi, I. (2015). Pengaruh Kecukupan Modal, Fungsi Intermediasi, Efisiensi Operasional, dan Pembiayaan Bermasalah terhadap Profitabilitas (Studi Pada Bank Syariah Periode Januari 2010-Juli 2014). Jurnal Ekonomi Syariah Teori dan Terapan, 2(3), 249-265. http://dx.doi.org/10.20473/vol2iss20153pp\%25p

Mawardi, W. (2005). Analisis Faktor-faktor yang Mempengaruhi Kinerja Keuangan Bank Umum di Indonesia (Studi Kasus pada Bank Umum dengan Total Asset kurang dari 1 Trilyun). Jurnal Bisnis Strategi, 14(1), 83-94. https://doi.org/10.14710/jbs.14.1.83-94

Molyneux, P., \& Thornton, J. (1992). Determinants of European Bank Profitability: A Note. Journal of Banking \& Finance, 16(6), 1173-1178. https://doi.org/10.1016/03784266(92)90065-8

Muchdarsyah, S. (2000). Manajemen Dana Bank. Jakarta: Bumi Aksara.

Rais, S. (2008). Faktor-faktor yang Mempengaruhi Mahasiswa untuk Tidak Menggunakan Bank Syariah: Studi di STIE Pengembangan Bisnis dan Manajemen, Jakarta. Jurnal Pengembangan Bisnis Dan Manajemen, 8(12).

Ramadan, I. Z., Kilani, Q. A., \& Kaddumi, T. A. (2011). Determinant of Bank Profitability: Evidence from Jordan. International Journal of Academic Research, 3(4), 180-191. Retrieved from http://web.asu.edu.jo/Upload/FacultyPub/dd898270-0e9d-4b8e8cfc-492ab22670bb.pdf

Sahara, Y. S. (2013). Analisis pengaruh inflasi, suku bunga BI, dan produk domestik bruto terhadap return on asset (ROA) bank syariah di Indonesia. Jurnal Ilmu Manajemen (JIM), 1(1), 149-157. Retrieved from https://jurnalmahasiswa.unesa.ac.id/index.php/jim/article/view/1502

Short, B. K. (1979). The Relation between Commercial Bank Profit Rates and Banking Concentration in Canada, Western Europe, and Japan. Journal of Banking \& Finance, 3(3), 209-219. https://doi.org/10.1016/0378-4266(79)90016-5

Steinherr, A., \& Huveneers, C. (1994). On the Performance of Differently Regulated Financial Institutions: Some Empirical Evidence. Journal of Banking \& Finance, 18(2), 271-306. https://doi.org/10.1016/0378-4266(94)00036-0

Sukirno, S. (2003). Pengantar Teori Mikro Ekonomi. Jakarta: Salemba Empat.

Wahyuni, Y. D. (2009). Analisis Faktor-faktor yang Berpengaruh terhadap Perilaku Masyarakat Santri yang Menjadi Nasabah dan Non Nasabah Bank Syariah (Studi di 


\section{Istan \& Fahlevi}

The Effect of External and Internal Factors on Financial Performance of Islamic Banking

Kabupaten Klaten dan Sukoharjo). Universitas Muhammadiyah Surakarta. Skripsi. Retrieved from http://eprints.ums.ac.id/id/eprint/3292

Yuliani, Y. (2007). Hubungan efisiensi operasional dengan kinerja profitabilitas pada sektor perbankan yang go publik di Bursa Efek Jakarta. Jurnal Manajemen dan Bisnis Sriwijaya, 5(10), 15-43. Retrieved from http://repository.unsri.ac.id/20579/

Yunus, M. (2008). Peranan Majelis Ulama Indonesia (MUI) dalam perkembangan dan sosialisasi perbankan syariah di Wilayah Riau, Indonesia (Doctoral dissertation, Jabatan Syariah dan Ekonomi, Akademi Pengajian Islam, Universiti Malaya). Retrieved from http://scholar.google.com/scholar?cluster $=11839081436019878759 \& h l=$ en\&oi=sch olarr 